\title{
ANALISIS PENDAPATAN USAHATANI PADI SAWAH \\ BERDASARKAN MUSIM PANEN DI KELURAHAN TARATARA SATU KECAMATAN TOMOHON BARAT KOTA TOMOHON.
}

\author{
Fremar Refel Welang, \\ Joachim N.K. Dumais, \\ Martha M. Sendow
}

\begin{abstract}
ABSRACT
This study aims to determine the magnitude of paddy rice farm income and determine how the feasibility of paddy rice farming by the harvest season in Taratara One Village, West Tomohon Sub-district, Tomohon City. The research was carried on three months, from Februari to April 2016, which is located in Taratara One Village. The Samples of farmers is using simple random sampling method (simple random). Data analysis in this research using descriptive analysis with the help of the table, and to determine the amount of income using the formula: $I=T R-T C$. And the feasibility of farming using analysis of return ratio by the formula: $a=R: C$. Based on the analysis, the average farm income of paddy rice farmer managed respondents in Taratara One Village by harvest season for the first harvest season 1 (one) Rp. 22,664,971.19 per hectare and the second harvest 2 (two) Rp. 18,541,100.85 per hectare. Rated Ratio/Cost for the first harvest season one (1) by 3.46 and harvest 2 (two) of 2.83. Based decision rule if the value of $R / C$ is more than one, it means paddy rice farming can provide benefits and well work the effort.
\end{abstract}

Keywords: paddy rice, farming income, Urban Village of Taratara, Tomohon City

\begin{abstract}
ABSTRAK
Penelitian ini bertujuan untuk mengetahui besarnya pendapatan usahatani padi sawah dan mengetahui bagaimana kelayakan usahatani padi sawah berdasarkan musim panen di Kelurahan Taratara Satu, Kecamatan Tomohon Barat, Kota Tomohon. Penelitian ini di laksanakan selama tiga bulan yaitu dari bulan Februari sampai April 2016, yang berlokasi di Kelurahan Taratara Satu. Penentuan sampel petani menggunakan metode Simple Random Sampling (acak sederhana). Analisis data dalam penelitian ini menggunakan analisis deskriptif dengan bantuan tabel, dan untuk mengetahui besarnya pendapatan menggunakan rumus: $I=T R-T C$. Dan kelayakan usahatani menggunakan analisis return rasio dengan rumus: $\mathrm{a}=\mathrm{R}: \mathrm{C}$. Berdasarkan hasil analisis data, rata-rata pendapatan usahatani padi sawah yang di kelola oleh petani responden di Kelurahan Taratara Satu berdasarkan musim panen, untuk musim panen 1 (satu) sebesar Rp. 22.664.971,19 per hektar dan musim panen 2 (dua) sebesar Rp. 18.541.100,85 per hektar. Nilai R/C untuk musim panen 1 (satu) sebesar 3,46 dan musim panen 2 (dua) sebesar 2,83. Berdasarkan kaidah keputusan apabila nilai R/C lebih dari satu, artinya usahatani padi sawah di Kelurahan Taratara Satu mampu memberikan keuntungan dan usahatani tersebut layak untuk di usahakan.
\end{abstract}

Kata kunci: pendapatan usahatani, padi sawah, Kelurahan Taratara Satu, Kota Tomohon

\section{PENDAHULUAN}

\section{Latar Belakang}

Indonesia merupakan Negara dengan keanekaragaman hayati yang sangat beragam, ditunjang karena ketersediaan sumber daya lahan yang luas dan subur, serta iklim yang cocok untuk kegiatan pertanian, memungkinkan Indonesia menjadi Negara agraris terbesar di dunia. Kebijakan yang ditempuh pemerintah untuk mewujudkan tujuan pembangunan nasional diantaranya adalah dengan peningkatan kehidupan ekonomi yang dilakukan melalui pembangunan pertanian.

Menurut Lynn (2003), pembangunan pertanian adalah bagian utuh dari pembangunan. Pembangunan pertanian juga adalah suatu proses yang ditujukan untuk selalu 
menambah produksi pertanian untuk tiap-tiap konsumen yang sekaligus mempertinggi pendapatan dan produktivitas usaha tiap-tiap petani dengan jalan menambah modal dan skill untuk memperbesar turut campur tangan manusia.

Produktivitas adalah rasio dari total output dengan input yang dipergunakan dalam produksi (Suwarto, 2012). Lebih lanjut Pindyck R.S dan D.L Rubinfeld (2001) mengungkapkan bahwa pengukuran produktivitas input sebagai jumlah output per unit input. Heady (1952) dalam Suwarto (2012), menjelaskan bahwa berkenan dengan lahan, produktivitas lahan berkesesuaian dengan kapasitas lahan untuk menyerap input produksi dan menghasilkan output dalam produksi pertanian.

Padi sebagai komoditas pangan utama mempunyai nilai strategis yang sangat tinggi, sehingga diperlukan adanya penanganan yang serius dalam upaya peningkatan produktivitasnya. Besarnya peranan pemerintah dalam pengelolahan komoditas pangan khususnya padi dapat dilihat mulai dari kegiatan pra produksi seperti penyediaan bibit unggul, pupuk, obat-obatan, sarana irigasi, kredit produksi dan penguatan modal kelembagaan petani. Usaha peningkatan produksi dan pendapatan usahatani padi tidak akan berhasil tanpa penggunaan teknologi baru baik dibidang teknis budidaya, benih, obatobatan dan pemupukan (Ilham, 2010).

Sub sektor tanaman bahan makanan merupakan salah satu sub sektor pada sektor pertanian. Sub sektor ini mencakup tanaman padi (padi sawah dan padi ladang), jagung, ubi kayu, ubi jalar, kacang tanah, dan kacang kedelai. Luas panen, Produksi, dan Produktivitas Padi Sawah di Kota Tomohon pada tahun 2014, sebesar 2699 ha, dengan jumlah Produksi 10.282 ton dan produktivitas 38,52 kuintal/ton. Gambaran mengenai penyebaran produksi padi di Kota Tomohon menunjukkan konsentrasi produksi padi pada kecamatan Tomohon Barat (BPS Kota Tomohon 2015). Produksi padi sawah di Kota Tomohon terus diupayakan guna memenuhi permintaan pasar komoditi beras yang terus meningkat seiring semakin pesatnya pertumbuhan penduduk.
Usahatani Padi Sawah di Kecamatan Tomohon Barat selama empat Tahun terakir dengan lima kali musim panen pada setiap dua tahunnya, produksinya sangat baik. Hal ini seperti yang di tunjukkan dalam Tabel 1, yang memperlihatkan selama empat tahun terakir dengan lima kali musim panen setiap dua tahun dengan luas tanam sebesar 22,285 ha untuk tahun 2012-2013 dan luas tanam sebesar 22.370 ha untuk tahun 2014-2015, produksi padi sawah di Kecamatan Tomohon Barat mengalami peningkatan untuk tahun 2012-2013 sebesar 158,223 ton dengan produktivitas 7,1 ton/ha dan tahun 2014-2015 sebesar 163,301 ton dengan produktivitas 7,3 ton/ha.

Tabel 1. Musim Panen, Luas Tanam, Produksi dan Produktivitas Komoditi Padi Sawah di Kecamatan Tomohon Barat

\begin{tabular}{ccccc}
\hline Tahun & $\begin{array}{c}\text { Musim } \\
\text { Panen }\end{array}$ & $\begin{array}{c}\text { Luas } \\
\text { Tanam } \\
\text { (ha) }\end{array}$ & $\begin{array}{c}\text { Produksi } \\
\text { (ton) }\end{array}$ & $\begin{array}{c}\text { Produktivitas } \\
\text { (ton/ha) }\end{array}$ \\
\hline 2012 & 5 & 22.285 & 158,223 & 7,1 \\
- & & & & \\
2013 & & & & 7.3 \\
\hline 2014 & 5 & 22.370 & 163,301 & \\
- & & & & \\
2015 & & & & \\
\hline
\end{tabular}

Sumber: Data Sekunder BP3K Kecamatan Tomohon Barat, 2016

Di Kelurahan Taratara Satu Kecamatan Tomohon Barat Kota Tomohon terdapat 30 petani yang mengusahakan padi sawah. Musim tanam padi sawah di Kelurahan Taratara Satu sebanyak lima kali dalam dua tahun, sehingga untuk satu kali musim tanam sampai pada musim panen memerlukan waktu 146 hari atau 4 bulan 3 minggu. Musim tanam adalah kegiatan dimana para petani mulai melakukan kegiatan usahataninya yang di mulai dari persemaian sampai pada pemeliharaan, sedangkan musim panen adalah kegiatan dimana para petani akan melakasanakan pemanenan padi sampai pada kegiatan penyimpanan dan penjualan. Kelurahan Taratara satu merupakan salah satu Kelurahan di Kecamatan Tomohon Barat Kota Tomohon, yang cukup berhasil dalam mengembangkan sektor pertanian. 


\section{Perbedaan dan Persamaan dengan Penelitian Terdahulu}

Penelitian yang hampir sama telah dilakukan pada sebelumnya oleh Gracela Kaparang, dengan judul "Kajian Usahatani Padi Sawah di Kelurahan Taratara Satu Kota Tomohon" Tujuan dalam penelitian sebelumnya ada dua yaitu: untuk mengkaji dan mendeskripsikan usahatani padi sawah dan untuk menganalisis besar pendapatan. Metode analisis data yang digunakan yaitu analisis deskriptif dengan bantuan tabel. Hasil dalam penelitian ini, menunjukkan bahwa pendapatan petani menguntungkan dan usahatani padi sawah layak dilanjutkan/dikembangkan, serta tahapan budidaya padi, sudah sesuai dengan standar yang berlaku. Persamaan dalam penelitian ini adalah peneliti terdahulu melakukan penelitian terhadap faktor yang sama yaitu pendapatan dan kelayakan usahatani sedangkan perbedaannya peneliti sebelumnya melakukan penelitian terhadap pendapatan, tahapan budidaya dan kelayakan usahatani, peneliti sekarang meneliti pendapatan dan kelayakan usahatani dan tidak meneliti menyangkut tahapan budidaya. Peneltitian sebelum hanya menyangkut satu musim tanam sedangkan penelitian ini menyangkut dua musim tanam.

\section{Perumusan Masalah}

Berdasarkan latar belakang, maka dapat dirumuskan masalah sebagai berikut:

1. Berapa besarnya pendapatan usahatani padi sawah berdasarkan musim panen di Kelurahan Taratara Satu Kecamatan Tomohon Barat Kota Tomohon?

2. Bagaimana kelayakan usahatani padi sawah berdasarkan musim panen di Kelurahan Taratara Satu Kecamatan Tomohon Barat Kota Tomohon?

\section{Tujuan Penelitian}

Berdasarkan latar belakang dan perumusan masalah, maka penelitian ini bertujuan:

1. Untuk mengetahui besarnya pendapatan usahatani padi sawah berdasarkan musim panen di Kelurahan Taratara Satu Kecamatan Tomohon Barat Kota Tomohon.

2. Untuk mengetahui bagaimana kelayakan usahatani padi sawah berdasarkan musim panen di Kelurahan Taratara Satu Kecamatan Tomohon Barat Kota Tomohon.

\section{Manfaat Penelitian}

1. Sebagai bahan informasi bagi pengambil kebijakan dalam upaya meningkatkan pendapatan dan perbaikan taraf hidup petani.

2. Sebagai bahan informasi dan perbandingan bagi peneliti lain yang akan melanjutkan penelitian ini.

\section{METODE PENELITIAN}

\section{Waktu dan Tempat Penelitian}

Penelitian ini berlangsung selama 3 (tiga) bulan dari tahap persiapan, pengambilan data dan sampai pada penyusunan penelitian. Dengan lokasi penelitian di Kelurahan Taratara Satu, Kecamatan Tomohon Barat, Kota Tomohon. Kelurahan Taratara Satu merupakan salah satu sentra produksi beras di Kota Tomohon.

\section{Metode Pengumpulan Data \\ Data yang dikumpulkan berupa data} primer dan data sekunder. Data primer diperoleh dengan cara observasi langsung ke lokasi penelitian dan wawancara langsung dengan responden dengan menggunakan daftar pertanyaan yang telah disusun sesuai dengan tujuan penelitian. Sedangkan data sekunder diperoleh dari instansi yang berhubungan dengan penelitian ini yaitu Badan Pusat Statistik (BPS) Kota Tomohon, Balai Penyuluhan Pertanian, Perikanan, Peternakan dan Kehutanan (BP3K) Kecamatan Tomohon Barat, dan Kantor Kelurahan Taratara Satu.

\section{Metode Pengambilan Sampel}

Pengambilan sampel dalam penelitian ini dengan menggunakan sampel acak sederhana (Simple Random Sampling). Di Kelurahan Taratara Satu Kecamatan Tomohon Barat Kota Tomohon terdapat 30 orang petani padi sawah. Salah satu cara untuk menentukan besarnya sampel dalam suatu penelitian agar data refresentatif adalah dengan menggunakan tingkat baku yang disesuaikan dengan tingkat kemampuan, tenaga, biaya, dan waktu yang tersedia, sehingga peneliti menetapkan untuk menggunakan tingkat presisi sebesar $9 \%$. 
Menurut Ridwan, (2005) dalam Iqbal, (2014) cara pengambilan sampel dapat menggunakan rumus slovin sebagai berikut:

$$
n=\frac{N}{N d^{2}+1}
$$

Keterangan: $\mathrm{n}=$ Sampel

$$
\begin{aligned}
& \mathrm{N}=\text { Jumlah Populasi } \\
& \mathrm{d}^{2}=\text { Tingkat presisi }(9 \%) \text { dengan }
\end{aligned}
$$

tingkat ketelitian sebesar $(91 \%)$

Berdasarkan rumus Slovin jumlah sampel sebagai berikut:

$$
\frac{30}{(30) 0,09^{2}+1}=\frac{30}{1.25}=24
$$

\section{Konsep Pengukuran Variabel}

Variabel-variabel yang akan di ukur dalam penelitian ini adalah:

1. Karakteristik Responden :

a. Umur: Usia Responden yang mengelolah usahatani padi sawah

b. Tingkat Pendidikan: Dilihat dari tingkat Pendidikan responden yang mengelolah usahatani padi sawah dibagi atas:

- Tamat SD

- Tamat SMP

- Tamat SMA/SMK dan Perguruan Tinggi.

c. Lama Usahatani

d. Status Kepemilikan lahan

2. Produksi Usahatani adalah jumlah produksi yang dihasilkan petani pada setiap musim panen dan dinyatakan dalam satuan $(\mathrm{Kg})$ baik yang dijual petani, maupun yang dikonsumsi oleh petani.

3. Harga jual adalah nilai jual produksi Usahatani (Kg) yang berlaku didaerah penelitian pada setiap musim panen (Rp).

4. Biaya Tetap adalah biaya yang dikeluarkan oleh petani responden untuk pembayaran pajak dan penyusutan peralatan pada setiap musim panen (Rp).

5. Biaya Variabel adalah semua biaya yang dikeluarkan oleh petani responden untuk biaya tenaga kerja baik TKDK (Tenaga Kerja Dalam Keluarga) dan TKLK (Tenaga Kerja Luar Keluarga), biaya sarana produksi, biaya sewa lahan, biaya sewa traktor, dan biaya sewa mesin perontok pada setiap musim panen $(\mathrm{Rp})$.
6. Biaya produksi adalah semua pengeluaran dalam setiap musim panen yang meliputi, Biaya tetap dan Biaya variabel (Rp).

\section{Analisis Data}

Data yang di peroleh dalam penelitian ini dianalisis dengan menggunakan metode analisis deskriptif dengan bantuan tabel, dan untuk mengetahui besarnya pendapatan yang di peroleh menggunakan rumus:

$$
\mathbf{I}=\mathbf{T R}-\mathbf{T C}
$$

Keterangan:

$\mathrm{I}=$ Pendapatan (Income)

$\mathrm{TR}=$ Total penerimaan (Total Revenue)

$\mathrm{TC}=$ Total biaya $($ Total Cost $)$

Untuk mengetahui kelayakan usahatani, maka di gunakan rumus Analisis Return Cost Ratio :

$$
\mathbf{a}=\mathbf{R}: \mathbf{C}
$$

Keterangan: $\quad \mathrm{a}=$ Return Cost Ratio

$\mathrm{R}=$ Return (Penerimaan)

$\mathrm{C}=$ Cost $($ Biaya $)$

Dengan kaidah keputusan:

Apabila:

$\mathrm{R} / \mathrm{C}=1$ maka Usahatani Tidak menguntungkan dan tidak rugi

$\mathrm{R} / \mathrm{C}<1$ maka Usahatani Rugi

$\mathrm{R} / \mathrm{C}>1$ maka Usahatani Untung

\section{HASIL DAN PEMBAHASAN}

\section{Kondisi Umum Kelurahan Taratara Satu}

\section{Letak Geografis}

Kelurahan Taratara Satu merupakan salah satu kelurahan di Kota Tomohon tepatnya di Kecamatan Tomohon Barat. Kelurahan Taratara Satu berbatasan dengan:

Sebelah Utara berbatasan dengan

Kelurahan Taratara Dua

Sebelah Selatan berbatasan dengan

Kelurahan Pinaras dan Desa Tincep

Sebelah Timur berbatasan dengan

Kelurahan Taratara Dua

Sebelah Barat berbatasan dengan

Kelurahan Taratara Induk dan Desa

Ranotongkor

Kelurahan Taratara Satu, terbagi atas 8 (Delapan) Lingkungan, dengan luas wilayah sebesar 625,5 ha/m² (Kantor Kelurahan Taratara Satu, 2016) yang meliputi: 
Luas Pemukiman

Luas Persawahan

Luas Perkebunan

Luas Pekarangan

Luas Taman

Luas Perkantoran

Prasarana Umum Lainnya

Keadaan Topografi Kelurahan Taratara

Satu berdataran rendah, berkawasan rawah dan dilalui oleh aliran sungai dengan kondisi iklim yang sejuk karena kelembaban udara sekitar 70 Persen $(\%)$ dan suhu rata-rata $25-30^{\circ} \mathrm{C}$.

\section{Luas Tanah berdasarkan Penggunaannya}

Penggunaan tanah di Kelurahan Taratara Satu terbagi atas Tanah Sawah seluas $250 \mathrm{ha} / \mathrm{m}^{2}$, Tanah Kering seluas $374,5 \mathrm{ha} / \mathrm{m}^{2}$, Tanah Perkebunan Rakyat seluas $200 \mathrm{ha} / \mathrm{m}^{2}$, Tanah Hutan seluas $150 \mathrm{ha} / \mathrm{m}^{2}$, dan Tanah Fasilitas Umum Lainnya seluas $7,50 \mathrm{ha} / \mathrm{m}^{2}$ (Kantor Kelurahan Taratara Satu, 2016). Penggunaan tanah di Kelurahan Taratara Satu tersaji dalam tabel-tabel berikut:

Tabel 2. Tanah Sawah berdasarkan Penggunaannya

\begin{tabular}{lc}
\hline \multicolumn{1}{c}{ Penggunaan } & Luas $\left(\mathbf{h a} / \mathbf{m}^{\mathbf{2}}\right)$ \\
\hline Sawah Irigasi Teknis & 100 \\
Sawah Irigasi 1/2 Teknis & 150 \\
Sawah Tadah Hujan & 0 \\
Sawah Pasang Surut & 0 \\
\hline \multicolumn{1}{c}{ Jumlah } & $\mathbf{2 5 0}$ \\
\hline
\end{tabular}

Sumber : Kantor Kelurahan Taratara Satu Tahun, 2016

Tabel 2 menunjukkan, untuk tanah sawah yang dikelolah oleh petani di Kelurahan Taratara Satu, berupa sawah irigasi teknis seluas 100 $\mathrm{ha} / \mathrm{m}^{2}$ dan sawah irigasi $1 / 2$ teknis seluas 150 $\mathrm{ha} / \mathrm{m}^{2}$.

Tabel 3. Tanah Kering Berdasarkan Penggunaannya

\begin{tabular}{lc}
\hline \multicolumn{1}{c}{ Penggunaan } & Luas $\left(\mathbf{h a} / \mathbf{m}^{\mathbf{2}}\right)$ \\
\hline Tegal/Ladang & 350 \\
Pemukiman & 20 \\
Pekarangan & 4,5 \\
\hline \multicolumn{1}{c}{ Jumlah } & $\mathbf{3 7 4 , 5}$
\end{tabular}

Sumber : Kantor Kelurahan Taratara Satu Tahun, 2016
Tabel 3 menunjukkan, untuk tanah kering di Kelurahan Taratara Satu sebagian besar digunakan untuk tegal/ladang seluas $350 \mathrm{ha} / \mathrm{m}^{2}$, pemukiman seluas $20 \mathrm{ha} / \mathrm{m}^{2}$, dan pekarangan seluas $4,5 \mathrm{ha} / \mathrm{m}^{2}$.

Tabel 4. Tanah Perkebunan Rakyat berdasarkan Penggunaannya

\begin{tabular}{lc}
\hline \multicolumn{1}{c}{ Penggunaan } & Luas $\left(\mathbf{h a} / \mathbf{m}^{\mathbf{2}}\right)$ \\
\hline Tanah Perkebunan Perorangan & 200 \\
Tanah Perkebunan Rakyat & 0 \\
Tanah Perkebunan Swasta & 0 \\
Tanah Perkebunan Negara & 0 \\
\hline Jumlah & $\mathbf{2 0 0}$
\end{tabular}

Sumber : Kantor Kelurahan Taratara Satu Tahun, 2016

Tabel 4 menunjukkan, untuk tanah perkebunan rakyat di Kelurahan Taratara Satu seluruhnya digunakan untuk Tanah Perkebunan Perorangan seluas $200 \mathrm{ha} / \mathrm{m}^{2}$.

Tabel 5. Tanah Hutan berdasarkan Penggunaannya

\begin{tabular}{lc}
\hline \multicolumn{1}{c}{ Penggunaan } & Luas $\left(\mathbf{h a} / \mathbf{m}^{\mathbf{2}}\right)$ \\
\hline Hutan Terbatas & 125 \\
Hutan Rakyat & 25 \\
\hline Jumlah & $\mathbf{1 5 0}$ \\
\hline Sumber : Kantor Kelurahan Taratara Satu Tahun, \\
2016
\end{tabular}

Tabel 5 menunjukkan, untuk tanah hutan di Kelurahan Taratara Satu sebagian besar digunakan untuk tanah hutan terbatas seluas 125 $\mathrm{ha} / \mathrm{m}^{2}$ dan tanah hutan rakyat seluas $25 \mathrm{ha} / \mathrm{m}^{2}$.

Tabel 6. Tanah Fasilitas Umum Berdasarkan Penggunaannya

\begin{tabular}{lc}
\hline \multicolumn{1}{c}{ Penggunaan } & Luas $\left(\mathbf{h a} / \mathbf{m}^{\mathbf{2}}\right)$ \\
\hline Perkantoran Pemerintah & 0,25 \\
Ruang Publik/Taman Kota & 0,75 \\
Bangunan Sekolah & 1 \\
Jalan & 3,5 \\
Usaha Perikanan & 1 \\
TPA & 1
\end{tabular}

\begin{tabular}{c}
\hline Jumlah \\
\hline $\begin{array}{c}\text { Sumber : Kantor Kelurahan Taratara Satu Tahun, } \\
2016\end{array}$
\end{tabular}


Tabel 6 menunjukkan, untuk tanah fasilitas umum di Kelurahan Taratara Satu sebagian besar di gunakan untuk pengunaan jalan seluas $3,5 \mathrm{ha} / \mathrm{m}^{2}$, diikuti untuk usaha perikanan, bangunan sekolah dan TPA masing-masing seluas $1 \mathrm{ha} / \mathrm{m}^{2}$, dan untuk ruang publik/taman kota seluas $0,75 \mathrm{ha} / \mathrm{m}^{2}$, serta perkantoran pemerintah seluas $0,25 \mathrm{ha} / \mathrm{m}^{2}$.

\section{Keadaan Penduduk}

Penduduk di Kelurahan Taratara Satu sampai pada Maret 2016 berjumlah 1.815 jiwa dengan jumlah Laki-laki sebanyak 949 jiwa dan perempuan sebanyak 866 jiwa. Jumlah kepala keluarga di Kelurahan Taratara Satu sebanyak 493 kepala keluarga. Untuk mengetahui klasifikasi penduduk di Kelurahan Taratara Satu berdasarkan umur, agama, pendidikan, dan pekerjaan dapat dilihat dalam tabel-tabel sebagai berikut:

\section{a. Penduduk Menurut Umur}

Penduduk di Kelurahan Taratara Satu, sebagian besar berumur produktif. Perincian jumlah penduduk di Kelurahan Taratara Satu menurut umur dapat dilihat dalam Tabel 7 berikut ini.

Tabel 7. Jumlah Penduduk Menurut Umur

\begin{tabular}{|c|c|c|c|}
\hline \multirow[t]{2}{*}{$\begin{array}{l}\text { Umur } \\
\text { (Tahun) }\end{array}$} & \multicolumn{2}{|c|}{$\begin{array}{c}\text { Jumlah Penduduk } \\
\text { (Jiwa) }\end{array}$} & \multirow[t]{2}{*}{$\begin{array}{l}\text { Jumlah } \\
\text { (Jiwa) }\end{array}$} \\
\hline & $\begin{array}{l}\text { Laki- } \\
\text { laki }\end{array}$ & Perempuan & \\
\hline $0-15$ & 231 & 121 & 424 \\
\hline $16-64$ & 650 & 571 & 1.221 \\
\hline 65 keatas & 68 & 102 & 170 \\
\hline Jumlah & 949 & 866 & 1.815 \\
\hline
\end{tabular}

Sumber : Data Sekunder Kelurahan Taratara Satu, Maret 2016

Tabel 7, terlihat bahwa jumlah penduduk di Kelurahan Taratara Satu sampai pada Maret 2016, yang berumur produktif 16-64 Tahun sebanyak 1.221 jiwa, dan non produktif sebanyak 594 jiwa yang terbagi dalam umur 0-15 Tahun sebanyak 424 jiwa dan yang berumur 65 Tahun keatas sebanyak 170 jiwa.

\section{b. Penduduk Menurut Agama}

Agama/Kepercayaan yang dianut oleh masyarakat di Kelurahan Taratara Satu ialah Kristen Protestan, Kristen Katholik, dan Islam. Perincian jumlah penduduk menurut agama/ kepercayaan dapat dilihat dalam Tabel 8 .
Tabel 8 terlihat bahwa, sebagian besar masyarakat di Kelurahan Taratara Satu, memeluk agama Kristen Katholik sebanyak 1.049 jiwa. Selanjutnya masyarakat yang beragama Kristen Protestan sebanyak 764 jiwa, dan Islam 2 jiwa.

Tabel 8. Jumlah Penduduk Menurut Agama/Kepercayaan

\begin{tabular}{lccc}
\hline \multicolumn{1}{c}{$\begin{array}{c}\text { Agama } \\
\text { (Kepercayaan) }\end{array}$} & \multicolumn{2}{c}{$\begin{array}{c}\text { Jumlah Penduduk } \\
\text { (Jiwa) }\end{array}$} & $\begin{array}{c}\text { Jumlah } \\
\text { (Jiwa) }\end{array}$ \\
\cline { 2 - 3 } & $\begin{array}{c}\text { Laki- } \\
\text { laki }\end{array}$ & Perempuan & \\
\hline Kristen & 390 & 374 & 764 \\
Protestan & & & \\
Kristen Katholik & 560 & 489 & 1.049 \\
Islam & 2 & 0 & 2 \\
\hline \multicolumn{1}{c}{ Jumlah } & $\mathbf{9 5 2}$ & $\mathbf{8 6 3}$ & $\mathbf{1 . 8 1 5}$ \\
\hline
\end{tabular}

Sumber : Data Sekunder Kelurahan Taratara Satu, Maret 2016

\section{c. Penduduk Menurut Pendidikan}

Penduduk di Kelurahan Taratara Satu, pada umumnya telah berpendidikan. Perincian jumlah penduduk di Kelurahan Taratara Satu menurut pendidikan dapat di lihat dalam Tabel 9.

Tabel 9. Jumlah Penduduk Menurut Pendidikan

\begin{tabular}{|c|c|c|c|}
\hline \multirow[t]{2}{*}{$\begin{array}{c}\text { Tingkat } \\
\text { Pendidikan }\end{array}$} & \multicolumn{2}{|c|}{$\begin{array}{c}\text { Jumlah } \\
\text { Penduduk (Jiwa) }\end{array}$} & \multirow{2}{*}{$\begin{array}{c}\text { Jumla } \\
\text { h } \\
\text { (Jiwa) }\end{array}$} \\
\hline & $\begin{array}{l}\text { Laki } \\
\text {-laki }\end{array}$ & $\begin{array}{c}\text { Perempua } \\
\text { n }\end{array}$ & \\
\hline $\begin{array}{l}\text { Tidak/Belum } \\
\text { Sekolah }\end{array}$ & 73 & 69 & 142 \\
\hline Belum Tamat SD & 116 & 90 & 206 \\
\hline Tamat SD & 212 & 186 & 398 \\
\hline Tamat SMP & 230 & 199 & 429 \\
\hline Tamat SMA/SMK & 279 & 269 & 548 \\
\hline $\begin{array}{l}\text { Tamat } \\
\text { Akademik/Diplo } \\
\text { ma }\end{array}$ & 9 & 13 & 22 \\
\hline $\begin{array}{l}\text { Tamat Perguruan } \\
\text { Tinggi }\end{array}$ & 34 & 36 & 70 \\
\hline Jumlah & 953 & 862 & 1815 \\
\hline
\end{tabular}

Sumber : Data Sekunder Kelurahan Taratara Satu, Maret 2016

Tabel 9 terlihat bahwa, sebagian besar Penduduk di Kelurahan Taratara Satu yakni sebanyak 1.697 jiwa atau sebesar 92,18 persen telah berpendidikan. Jumlah penduduk yang 
telah berpendidikan meliputi belum tamat SD sebanyak 206 jiwa, tamat SD sebanyak 398 jiwa, tamat SMP sebanyak 429 jiwa, tamat SMA/SMK sebanyak 548 jiwa, tamat Akademik/Diploma sebanyak 22 jiwa, dan tamat Perguruan Tinggi sebanyak 70 jiwa. Selebihnya yang berjumlah 142 jiwa atau sekitar 8,82 persen ialah penduduk yang tidak/belum sekolah atau yang masih ditingkat TK/Play group dan yang tidak bersekolah.

\section{d. Jumlah Penduduk Menurut Pekerjaan}

Pekerjaan yang menopang kehidupan masyarakat di Kelurahan Taratara Satu bervarias. Sebagian besar masyarakat di Kelurahan Taratara Satu sudah bekerja dengan berbagai profesi pekerjaan. Rincian pekerjaan masyarakat Kelurahan Taratara Satu, disajikan dalam Tabel 10.

Tabel 10 menunjukkan bahwa, masyarakat di Kelurahan Taratara Satu yang sudah bekerja sebanyak 1.122 jiwa atau sekitar 61,82 persen, pelajar/mahasiswa sebanyak 454 jiwa atau sekitar 20 persen dan yang belum bekerja sebanyak 239 atau sekitar 18,18 persen.

\section{Karakteristik Responden Usahatani Padi Sawah}

\section{Umur Responden}

Tingkat umur berpengaruh terhadap cara atau pola pikir dan kemampuan fisik seseorang untuk bekerja. Seseorang yang bekerja pada sektor pertanian pasti mangandalkan kemampuan fisik, sehingga fisik yang prima sangat diperlukan. Hal ini penting karena akan mempengaruhi produktivitas kerja petani, umur juga berpengaruh kepada kemampuan berpikir petani dalam rangka pengambilan keputusan yang tepat untuk mengalokasikan saprodi yang dibutuhkan dan juga dapat mempengaruhi kemampuan manajerial petani. Namun demikian, umur yang relativ mudah bukanlah merupakan suatu jaminan akan keberhasilan dalam berusahatani. Jumlah petani padi sawah di kelurahan Taratara Satu menurut golongan umur dapat dilihat pada Tabel 11 .

Pada Tabel 11, menunjukkan bahwa kisaran umur responden petani padi sawah di Kelurahan Taratara Satu yaitu 40-55 tahun. Sebagian besar responden petani padi sawah berada pada kelompok umur 45-50 tahun, dengan jumlah petani yaitu sebanyak 11 orang atau 45,83 persen dari jumlah responden. Selebihnya berada pada kelompok umur 51-55 tahun, sebanyak 9 orang atau 37,50 persen, dan umur 40-44 tahun, sebanyak 4 orang atau 16,67 persen dari jumlah responden petani.

Tabel 10. Jumlah Penduduk Munurut Pekerjaan

\begin{tabular}{lccc}
\hline \multicolumn{1}{c}{$\begin{array}{c}\text { Jenis } \\
\text { Pekerjaan }\end{array}$} & \multicolumn{2}{c}{ Jumlah Penduduk (jiwa) } & Jumlah \\
\cline { 2 - 3 } (jiwa)
\end{tabular}

Sumber : Data Sekunder Kelurahan Taratara Satu, Maret 2016 
Tabel 11. Jumlah Petani Menurut Golongan Umur

\begin{tabular}{ccc}
\hline Golongan & \multicolumn{2}{c}{ Petani } \\
\cline { 2 - 3 } $\begin{array}{c}\text { Umur } \\
\text { Petani }\end{array}$ & $\begin{array}{c}\text { Jumlah } \\
\text { (Orang) }\end{array}$ & $\begin{array}{c}\text { Persentase } \\
(\text { \% })\end{array}$ \\
\hline $40-44$ & 4 & 16,67 \\
$45-50$ & 11 & 45,83 \\
$51-55$ & 9 & 37,50 \\
\hline Jumlah & $\mathbf{2 4}$ & $\mathbf{1 0 0 , 0 0}$ \\
\hline
\end{tabular}

Sumber : Data Primer, 2016

\section{Tingkat Pendidikan Responden}

Makin tinggi tingkat pendidikan seseorang makin mudah menerima informasi sehingga makin banyak pula pengetahuan yang dimiliki. Sebaliknya pendidikan yang kurang akan menghambat perkembangan sikap seseorang terhadap nilai-nilai yang baru diperkenalkan.

Dengan demikian, dapat dikatakan petani yang berpendidikan akan lebih mudah menerima berbagai informasi mengenai perkembangan teknologi dan inovasi-inovasi terbaru dan lebih mampu memilah informasiinformasi tersebut untuk diimplementasikan kedalam usahataninya.

Berikut jumlah petani yang ada di Kelurahan Taratara Satu menurut tingkat pendidikan yang terangkum dalam Tabel 12 .

Tabel 12. Jumlah Petani Menurut Tingkat Pendidikan

\begin{tabular}{lcc}
\hline \multicolumn{1}{c}{$\begin{array}{c}\text { Tingkat } \\
\text { Pendidikan } \\
\text { Responden }\end{array}$} & \multicolumn{2}{c}{ Petani } \\
\cline { 2 - 3 } & Jumlah & $\begin{array}{c}\text { Persentase } \\
\text { (Orang) }\end{array}$ \\
\hline Tamat SD & 3 & 12,50 \\
Tamat SMP & 6 & 25,00 \\
Tamat & 15 & 62.50 \\
SMA/SMK & & \\
\hline \multicolumn{1}{c}{ Jumlah } & $\mathbf{2 4}$ & $\mathbf{1 0 0 , 0 0}$ \\
\hline
\end{tabular}

Sumber : Data Primer, 2016

Hasil penelitian yang terangkum pada Tabel 12, menunjukkan bahwa tingkat pendidikan responden petani padi sawah di Kelurahan Taratara Satu termasuk dalam kategori cukup tinggi. Hal ini terlihat pada tingkat pendidikan SMA/SMK yang memiliki nilai presentase sebesar 62,50 persen dari total responden petani atau sebanyak 15 orang responden petani. selebihnya berada pada tingkat pendidikan SMP sebesar 25,00 persen dari total petani responden atau sebanyak 6 orang, dan tingkat pendidikan SD sebesar 12,50 persen atau sebanyak 3 orang dari total petani responden.

\section{Lama Berusahatani}

Lamanya berusahatani membentuk petani menjadi lebih berpengalaman dan memiliki banyak pengetahuan terutama tentang usahatani yang dikelolahnya. Berikut jumlah petani menurut lama berusahatani yang terangkum dalam Tabel 13.

\section{Tabel 13. Jumlah Petani Menurut Lama} Berusahatani

\begin{tabular}{ccc}
\hline \multirow{2}{*}{ Lama } & \multicolumn{2}{c}{ Petani } \\
\cline { 2 - 3 } & $\begin{array}{c}\text { Jumlah } \\
\text { (Orang) }\end{array}$ & $\begin{array}{c}\text { Persentase } \\
(\mathbf{\%})\end{array}$ \\
\hline$<10$ & 10 & 41,67 \\
$11-20$ & 9 & 37.50 \\
$>21$ & 5 & 20,83 \\
\hline Jumlah & $\mathbf{2 4}$ & $\mathbf{1 0 0 , 0 0}$ \\
\hline
\end{tabular}

Sumber : Data Primer, 2016

Pada Tabel 13, menunjukkan bahwa responden petani padi sawah di Kelurahan Taratara Satu, untuk lama berusahatani yakni sebanyak 10 petani atau sebesar 41,67 persen dari jumlah petani responden berusahatani padi sawah selama $<10$ tahun, diikuti sebanyak 9 petani atau sebesar 37,50 persen dari jumlah petani responden berusahatani padi sawah selama 11-20 tahun, dan 5 petani atau sebesar 20,83 persen dari jumlah responden berusahatani $>21$ tahun.

\section{Status Kepemilikan Lahan}

Status kepemilikan lahan berpengaruh dalam pendapatan usahatani padi sawah di Kelurahan Taratara Satu. Dalam pengelolaan usahatani padi sawah di Kelurahan Taratara Satu, ada petani yang mengelolah sendiri usahataninya atau berstatus sebagai pemilik, dan ada juga yang mengelolah usahataninya bukan milik sendiri atau berstatus penggarap, dengan pembagian 1/3 dari hasil usahataninya. 
Rata-rata biaya sewa lahan petani penggarap pada musim panen 1 (satu) sebesar Rp. 1.454,802,26 per hektar. Musim panen 2 (dua) sebesar Rp. 1.317.090,40 per hektar. Hasil penelitian menunjukkan bahwa perbedaan biaya sewa lahan oleh petani penggarap pada musim panen 1 (satu) dan musim panen 2 (dua) dikarenakan oleh hasil produksi padi yang di produksi oleh petani berbeda dari musim panen 1 (satu) dan musim panen 2 (dua).

Untuk mengetahui jumlah petani responden yang mengelolah usahatani padi sawah di Kelurahan Taratara Satu menurut status kepemilikan lahan dapat dilihat pada Tabel 14.

Tabel 14. Jumlah Petani Menurut Status Kepemilikan

\begin{tabular}{|c|c|c|}
\hline \multirow{2}{*}{$\begin{array}{c}\text { Tingkat } \\
\text { Pendidikan } \\
\text { Responden }\end{array}$} & \multicolumn{2}{|c|}{ Petani } \\
\hline & $\begin{array}{l}\text { Jumlah } \\
\text { (Orang) }\end{array}$ & $\begin{array}{c}\text { Persentase } \\
(\%)\end{array}$ \\
\hline Pemilik & 10 & 41,67 \\
\hline Penggarap & 14 & 58,33 \\
\hline Jumlah & 24 & 100,00 \\
\hline
\end{tabular}

Sumber : Data Primer, 2016

Pada Tabel 14, menunjukkan bahwa sebagian besar petani responden di Kelurahan Taratara Satu, atau sebanyak 14 orang petani dari jumlah responden berstatus sebagai petani penggarap, dengan presentase 58,33 persen dan sisanya atau sebanyak 10 orang petani dari jumlah responden berstatus sebagai pemilik atau mengusahakan sendiri usahataninya dengan presentase 41,67 persen.

\section{Luas Tanam, Produksi dan Harga Jual Usahatani Padi Sawah Berdasarkan Musim Panen}

\section{Luas Tanam}

Lahan merupakan salah satu faktor produksi yang sangat penting dalam kegiatan usahatani padi, karena merupakan media tanam yang digunakan untuk budidaya dalam usahatani. Luas tanam adalah besarnya luasan lahan yang dikelolah dalam berusahatani untuk menghasilkan produksi padi. Hasil penelitian menujukkan bahwa rata-rata luas tanam usahatani padi sawah di Kelurahan Taratara Satu berdasarkan musim panen 1 (satu) dan musim panen 2 (dua), untuk luas tanam sama yaitu seluas 0,59 hektar.
Jumlah petani menurut luas tanam padi sawah di Kelurahan Taratara Satu berdasarkan musim panen 1 (satu) dan musim panen 2 (dua) dapat dilihat pada Tabel 15.

Tabel 15. Jumlah Petani Menurut Luas Tanam Berdasarkan Musim Panen

\begin{tabular}{ccc}
\hline \multirow{2}{*}{$\begin{array}{c}\text { Luas Tanam } \\
\text { (Ha) }\end{array}$} & \multicolumn{2}{c}{ Petani } \\
\cline { 2 - 3 } & $\begin{array}{c}\text { Jumlah } \\
\text { (Orang) }\end{array}$ & $\begin{array}{c}\text { Persentase } \\
(\boldsymbol{\%})\end{array}$ \\
\hline $0,3-0,5$ & 15 & 62,50 \\
$0,6-0,8$ & 3 & 12,50 \\
$>0.9$ & 6 & 25,00 \\
\hline Jumlah & $\mathbf{2 4}$ & $\mathbf{1 0 0 , 0 0}$ \\
\hline
\end{tabular}

Sumber : Data Primer, 2016

Pada Tabel 15, diketahui bahwa luas tanam petani padi sawah berdasarkan musim panen, untuk musim panen 1 (satu) dan musim panen 2 (dua) di Kelurahan Taratara Satu bervariasi, 15 petani responden memiliki luas tanam 0,3-0,5 hektar dengan presentase sebesar 62,50 persen dari jumlah petani responden, selanjutnya 6 petani responden memiliki luas tanam > 0,9 hektar dengan presentase 25,00 persen dari jumlah petani responden, dan 3 petani responden memiliki luas tanam 0,6-0,8 hektar dengan presentase sebesar 12,50 persen dari jumlah petani responden.

\section{Produksi Usahatani Padi Sawah}

Produksi adalah suatu hasil dari kegiatan mengkombinasikan faktor-faktor produksi yaitu modal, tenaga kerja, teknologi dan managerial skill untuk meningkatkan manfaat. Besar kecilnya pendapatan petani sangat bergantung pada volume produksi. Semakin besar volume produksi yang dihasilkan maka semakin tinggi pula penerimaan yang akan diterima.

Produksi padi sawah di Kelurahan Taratara Satu berbentuk gabah kering. Rata-rata produksi beras yang di hasilkan petani untuk musim panen 1 (satu) dan musim panen 2 (dua), dapat dilihat dalam Tabel 16.

Tabel 16. Rata-rata Produksi Beras Berdasarkan Musim Panen

\begin{tabular}{cc}
\hline Musim Panen & Produksi \\
& (kg/ha) \\
\hline Musim Panen 1 & $3.347,89$ \\
Musim Panen 2 & $2.857,39$ \\
\hline
\end{tabular}

Sumber : Data Primer, 2016 
Tabel 16, menunjukkan rata-rata produksi beras petani responden padi sawah di Kelurahan Taratara Satu pada setiap musim panen yaitu, musim panen 1 (satu) sebanyak 3.347,89 kilogram beras per hektar, dan musim panen 2 (dua) sebanyak 2.857,39 kilogram beras per hektar. Hasil penelitian menunjukkan bahwa perbedaan jumlah produksi untuk musim panen 1 (satu) dan musim panen 2 (dua) di karenakan kondisi iklim pada saat proses usahatani.

\section{Harga Jual}

Harga jual yang berlaku pada saat penelitian dilakukan, untuk musim panen 1 (satu) dan musim panen 2 (dua) berbeda. Untuk harga jual musim panen 1 (satu) pada saat penelitian yaitu Rp. 9.500 per kilogram beras, dan harga jual untuk musim panen 2 (dua) pada saat penelitian yaitu Rp. 10.000 per kilogram beras.

\section{Biaya-biaya Usahatani Padi Sawah berdasarkan Musim Panen}

\section{Biaya Sarana Produksi}

Biaya saprodi adalah total biaya yang digunakan untuk pembelian sarana produksi dalam usahatani. Sarana produksi yang digunakan oleh petani responden dalam usahatani padi sawah di Kelurahan Taratara Satu meliputi, benih, pupuk, dan pestisida. Biaya saprodi di peroleh melalui hasil perkalian jumlah saprodi yang digunakan dengan harga jual yang berlaku. Rata-rata biaya saprodi (pupuk, benih, dan pestisida) pada usahatani padi sawah di Kelurahan Taratara Satu berdasarkan musim panen 1 (satu) dan musim panen 2 (dua) dapat di lihat pada Tabel 17.

Tabel 17 menunjukkan bahwa ratarata biaya sarana produksi petani padi sawah di Kelurahan Taratara Satu untuk musim Panen 1 (satu) sebesar Rp. 1.256.901,41 per hektar, dan untuk musim panen 2 (dua) sebesar Rp. 1.414.366,20 per hektar. Hasil penelitian mendapati bahwa biaya pupuk merupakan kontribusi terbesar penyusun biaya saprodi baik musim panen 1(satu) maupun musim panen 2 (dua). Biaya pupuk untuk musim panen 1 (satu) sebesar Rp. 764.296,28 per hektar dengan presentase sebesar 60,81 persen, dengan komposisi penyusun biaya pembelian pupuk sebagai berikut: Urea sebesar Rp. 256.690,14 per hektar, TSP/SP36 sebesar Rp. 234.330,99 per hektar, KCL sebesar Rp. 55.563,88 per hektar, dan NPK sebesar Rp. 217.711,27 per hektar. Untuk musim panen 2 (dua) sebesar Rp. 814.894,37 per hektar dengan presentase sebesar 57,62 persen, dengan komposisi penyusun biaya pembelian pupuk sebagai berikut: Urea sebesar Rp. 308.802,82 per hektar, TSP/SP36 sebesar Rp. 243.661,97 per hektar, KCL sebesar Rp. 42.253,52 per hektar, dan NPK sebesar Rp. 220.176,06 per hektar. Selanjutnya diikuti oleh biaya benih, untuk musim panen 1 (satu) sebesar Rp. 404.929,58 per hektar dengan presentase sebesar 32,22 persen, musim panen 2 (dua) sebesar Rp. 495.246,48 per hektar dengan presentase sebesar 35,01 persen, dan biaya pestisida untuk musim panen 1 (satu) sebesar Rp. 87.676,06 per hektar dengan presentase sebesar 6,97 persen, musim panen 2 (dua) sebesar Rp. 104.225,35 per hektar dengan presentase sebesar 7,37 persen.

\section{Biaya Penyusutan Peralatan}

Peralatan merupakan sarana penunjang kegiatan usahatani yang perlu dimiliki oleh petani. Peralatan yang digunakan oleh petani responden padi sawah di Kelurahan Taratara Satu antara lain: cangkul, sabit, parang, mesin perontok, alat penyemprot/speyer, dan mesin paras. Tidak semua peralatan tersebut dimiliki oleh petani di Kelurahan Taratara Satu. Hal ini dikarenakan harga peralatan yang tidak di jangkau oleh petani.

Biaya penyusutan peralatan petani sangat berpengaruh terhadap biaya tetap yang akan dikeluarkan oleh petani. biaya penyusutan ini dilakukan untuk menghitung nilai investasi alatalat pertanian yang menyusut setiap tahunnya. Penghitungan nilai penyusutan yaitu dengan menggunakan metode garis lurus antara nilai beli dan umur ekonomis peralatan tersebut. Nilai penyusutan peralatan usahatani padi sawah di Kelurahan Taratara Satu berdasarkan musim panen 1 (satu) dan musim panen 2 (dua) dapat di lihat pada Tabel 18. Pada Tabel 18 menunjukkan 
bahwa rata-rata biaya penyusutan peralatan pada usahatani padi sawah berdasarkan musim panen di Kelurahan Taratara Satu untuk musim panen 1 (satu) berjumlah Rp. 480.704,79 per hektar dan musim panen 2 (dua) berjumlah Rp. 328.451,55 per hektar. Hasil penelitian menunjukkan bahwa perbedaan biaya penyusutan peralatan untuk musim panen 1 (satu) dan musim panen 2 (dua) dipengaruhi oleh kondisi harga dan umur ekonomis alat tersebut. Kontribusi terbesar terhadap pembentukan biaya penyusutan peralatan usahatani untuk musim panen 1 (satu) dan musim panen 2 (dua) yaitu pada mesin perontok. Biaya penyusutan mesin perontok pada musim panen 1 (satu) sebesar Rp. 344.287,89 per hektar atau 71,62 persen, dan pada musim panen 2 (dua) sebesar Rp. 235.915,49 per hektar atau 71,83 persen. Peralatan usahatani yang memberikan kontribusi biaya penyusutan terendah berdasarkan musim panen 1 (satu) dan musim panen 2 (dua) yaitu pada peralatan sabit. Untuk musim panen 1 (satu) berjumlah Rp. 6.530,77 per hektar atau 1,36 persen, dan musim panen 2 (dua) berjumlah Rp. $4.260,77$ per hektar atau 1.30 persen.

\section{Biaya Tenaga Kerja}

Biaya tenaga kerja merupakan hasil perkalian Hari Orang Kerja (HOK) dengan upah tenaga kerja. Perhitungan biaya tenaga kerja di dasarkan pada sistim pembayaran upah tenaga kerja yang berlaku di Kelurahan Taratara Satu. Pembayaran upah tenaga kerja untuk musim panen 1 (satu) sebesar Rp. 75.000 sampai Rp. 100.000 dan untuk musim panen 2 (dua) sebesar Rp. 100.000 sampai Rp. 125.000. Hasil penelitian menunjukkan bahwa perbedaan pembayaran upah Tenaga Kerja dikarenakan upah pada setiap tahunnya berubah atau mengalami kenaikan, dan pembayaran upah tenaga kerja tidak termasuk dengan biaya lainnya seperti rokok, permen, teh atau kopi, dan makanan. Pembayaran upah untuk tenaga kerja pria dan wanita, pembayarannya sama.

Proses kegiatan yang dilakukan dalam usahatani padi sawah di Kelurahan Taratara Satu yang menggunakan tenaga kerja manusia yaitu: persemaian, penanaman, pemupukan, pemeliharaan, panen dan pasca panen. Sedangkan untuk pengolahan tanah petani di Kelurahan Taratara Satu menggunakan tenaga mesin hen tractor dengan rata-rata biaya sewa per hektar untuk musim panen 1 (satu) Rp. 1.260.563,38 per hektar dan musim panen 2 (dua) Rp. 1.609.154,93 per hektar. Hasil penelitian menunjukkan bahwa perbedaan biaya pembayaran sewa traktor untuk musim panen 1 (satu) dan musim panen 2 (dua) dikarenakan kondisi tanah yang sulit untuk dibajak. Pada musim panen 1 (satu) perairan di sawah baik, sehingga proses pembajakan tidak terlalu sulit dan struktur tanah tidak keras, sedangkan pada musim panen 2 (dua) struktur tanah keras karena kemarau panjang, sehingga debit air berkurang sehingga air yang mengairi tanah persawahan berkurang sehingga menyebapkan struktur tanah menjadi keras.

Rata-rata biaya tenaga kerja petani padi sawah di Kelurahan Taratara Satu, baik Tenaga Kerja Dalam Keluarga (TKDK) dan Tenaga Kerja Luar Keluarga (TKLK) untuk masing-masing kegiatan usahatani padi sawah berdasarkan musim panen di sajikan dalam Tabel 20.

Tabel 17. Rata-rata Biaya Sarana Produksi Usahatani Padi Sawah berdasarkan Musim Panen.

\begin{tabular}{|c|c|c|c|c|}
\hline \multirow{2}{*}{$\begin{array}{c}\text { Sarana } \\
\text { Produksi }\end{array}$} & \multicolumn{2}{|c|}{ Rata-rata Biaya (Rp/Ha) } & \multicolumn{2}{|c|}{ Persentase (\%) } \\
\hline & Panen 1 & Panen 2 & Panen 1 & Panen 2 \\
\hline Benih & 409.929,58 & 495.246,48 & 32,22 & 35,01 \\
\hline Pupuk & $764.296,28$ & 814.894,37 & 60,81 & 57,62 \\
\hline - Urea & $256.690,14$ & $308.802,82$ & & \\
\hline TSP/SP36 & $234.330,99$ & $243.661,97$ & & \\
\hline KCL & $55.563,88$ & $42.253,52$ & & \\
\hline - NPK & $217.711,27$ & $220.176,06$ & & \\
\hline Pestisida & $87.676,06$ & $104.225,35$ & 6,97 & 7,37 \\
\hline Jumlah & $1.256 .901,41$ & 1.414.366,20 & 100,00 & 100,00 \\
\hline
\end{tabular}

Sumber : Data Primer, 2016 
Tabel 18. Rata-rata Biaya Penyusutan Peralatan Usahatani Padi Sawah Berdasarkan Musim Panen

\begin{tabular}{|c|c|c|c|c|}
\hline \multirow{2}{*}{$\begin{array}{l}\text { Peralatan } \\
\text { Usahatani }\end{array}$} & \multicolumn{2}{|c|}{ Rata-rata Biaya (Rp/Ha) } & \multicolumn{2}{|c|}{ Presentase (\%) } \\
\hline & Panen 1 & Panen 2 & Panen 1 & Panen 2 \\
\hline Cangkul & $15.746,90$ & $9.377,39$ & 3,28 & 2,85 \\
\hline Sabit & $6.530,77$ & $4.260,77$ & 1,36 & 1,30 \\
\hline Parang & $12.842,11$ & $9.197,46$ & 2,67 & 2,80 \\
\hline Mesin Perontok & $344,287,89$ & 235.915 .49 & 71,62 & 71,83 \\
\hline Alat Penyemprot/Speyer & $43.173,38$ & $26.918,87$ & 8,98 & 8,20 \\
\hline Mesin Paras & $58.123,73$ & $42.781,55$ & 12,09 & 13,02 \\
\hline Jumlah & $480.704,79$ & $328.451,55$ & 100,00 & 100,00 \\
\hline
\end{tabular}

Sumber : Data Primer, 2016

Tabel 19. Rata-rata Biaya Tenaga Kerja Usahatani Padi Sawah Berdasarkan Musim Panen

\begin{tabular}{|c|c|c|c|}
\hline \multicolumn{4}{|c|}{ Musim Panen 1} \\
\hline \multirow{2}{*}{$\begin{array}{l}\text { Kegiatan } \\
\text { Usahatani }\end{array}$} & \multicolumn{2}{|c|}{ Rata-rata Biaya (Rp/Ha) } & \multirow{2}{*}{$\begin{array}{c}\text { Total Biaya } \\
(\mathrm{Rp} / \mathrm{Ha})\end{array}$} \\
\hline & TKDK & TKLK & \\
\hline Persemaian & $150.352,11$ & $122.183,10$ & $272.535,21$ \\
\hline Penanaman & $238.380,28$ & $837.676,06$ & $1.076 .056,34$ \\
\hline Pemupukan & $178.169,01$ & $88.732,39$ & $266.901,40$ \\
\hline Pemeliharaan & $364.084,51$ & $346.126,76$ & $710.211,27$ \\
\hline Panen/Pasca Panen & $347.535,21$ & $1.419 .718,31$ & $1.767 .253,52$ \\
\hline \multirow[t]{2}{*}{ Total } & 1.278.521,12 & $2.814 .436,62$ & 4.092.957,75 \\
\hline & \multicolumn{2}{|c|}{ Musim Panen 2} & \\
\hline \multirow{2}{*}{$\begin{array}{c}\text { Kegiatan } \\
\text { Usahatani }\end{array}$} & \multicolumn{2}{|c|}{ Rata-rata Biaya (Rp/Ha) } & Total Biaya \\
\hline & TKDK & TKLK & $(\mathbf{R p} / \mathbf{H a})$ \\
\hline Persemaian & $199.647,89$ & $86.267,61$ & $285.915,50$ \\
\hline Penanaman & $266.549,30$ & $1.034 .859,15$ & $1.301 .408,45$ \\
\hline Pemupukan & $243.661,97$ & $54.577,46$ & $298.239,43$ \\
\hline Pemeliharaan & $469.718,31$ & $441.197,18$ & $910.915,49$ \\
\hline Panen/Pasca Panen & $435.704,23$ & $1.633 .098,59$ & $2.068 .802,82$ \\
\hline $\begin{array}{l}\text { Total } \\
\end{array}$ & $1.615 .281,70$ & $3.249 .999,99$ & $4.865 .281,69$ \\
\hline
\end{tabular}

Sumber : Data Primer, 2016

Tabel 19 menunjukkan bahwa kegiatan usahatani padi sawah di Kelurahan Taratara Satu berdasarkan musim panen 1 (satu) dan musim panen 2 (dua) untuk proses kegiatan usahatani yang membutuhkan biaya tenaga kerja yang tinggi, yaitu pada kegiatan penanaman dan panen/pasca panen. Rata-rata biaya tenaga kerja terbesar yaitu pada kegiatan panen/pasca panen. Berdasarkan dua musim panen yang ada, untuk biaya tenaga kerja pada musim panen 1 (satu) untuk kegiatan panen/pasca panen sebesar Rp. 1.767.253,52 per hektar dengan komposisi biaya TKDK Rp.
347.535,21 per hektar dan biaya TKLK Rp. 1.419.718,31 per hektar. Biaya tenaga kerja pada musim panen 2 (dua) untuk kegiatan panen/pasca panen sebesar Rp. 2.068.802,82 per hektar dengan komposisi biaya TKDK Rp. 435.704,23 per hektar dan biaya TKLK Rp. 1.633.098,59 per hektar.

Kegiatan usahatani padi sawah yang rata-rata biaya tenaga kerjanya rendah, untuk musim panen 1 (satu) untuk kegiatan pemupukan sebesar Rp. 266.901,40 per hektar dengan komposisi biaya TKDK Rp. 178.169,01 per hektar dan biaya TKLK Rp 
$88.732,39$ per hektar. Biaya tenaga kerja pada musim panen 2 (dua) yang rata-rata biaya tenaga kerjanya rendah yaitu pada kegiatan persemaian sebesar Rp. 285.915,50 per hektar dengan komposisi biaya TKDK Rp. 199.647,89 per hektar dan biaya TKLK Rp. $86.267,61$ per hektar.

Hasil penelitian menunjukkan bahwa pada musim panen 1 (satu) dan musim panen 2 (dua) untuk kegiatan persemaian dan pemupukan, petani tidak terlalu membutuhkan tenaga tenaga kerja dari luar keluarga. Hal ini terlihat dari jumlah biaya tenaga kerja yang menunjukkan bahwa jumlah biaya TKLK lebih kecil dari jumlah biaya TKDK.

Rata-rata total biaya tenaga kerja yang dikeluarkan petani padi sawah di Kelurahan Taratara Satu untuk musim panen 1 (satu) berjumlah Rp. 4.092.957,75 per hektar yang terbagi atas TKDK Rp. 1.278.521,12 per hektar dan TKLK 2.814.436,62 per hektar. Pada musim panen 2 (dua) berjumlah $\mathrm{Rp}$. 4.865.281,69 per hektar yang terbagi atas TKDK Rp. 1.615.281,70 per hektar dan TKLK 3.249.999,99 per hektar.

\section{Biaya Tetap Usahatani Padi Sawah}

Biaya tetap usahatani padi sawah di Kelurahan Taratara Satu, yang dimaksutkan pada penelitian ini meliputi pajak tanah dan penyusutan peralatan yang digunakan petani responden padi sawah dalam keseluruhan proses usahatani padi sawah sampai pada penjualan.

Dalam penelitian ini, rata-rata untuk biaya pajak tanah dan Penyusutan peralatan petani responden padi sawah di Kelurahan Taratara Satu untuk musim panen 1 (satu) dan musim panen 2 (dua) dapat dilihat dalam Tabel 20

\begin{tabular}{ccc} 
Tabel 20. & $\begin{array}{c}\text { Rata-rata Biaya Tetap Usahatani } \\
\text { berdasarkan Musim Panen }\end{array}$ \\
\hline Musim Panen & \multicolumn{2}{c}{$\begin{array}{c}\text { Rata-rata Biaya Tetap } \\
\text { (Rp/Ha) }\end{array}$} \\
\cline { 2 - 3 } & Pajak & $\begin{array}{c}\text { Penyusutan } \\
\text { Peralatan }\end{array}$ \\
\hline Musim Panen 1 & $4.929,58$ & $480.704,79$ \\
Musim Panen 2 & $4.929,58$ & $328.451,55$ \\
\hline
\end{tabular}

Sumber : Data Primer, 2016

Tabel 20 menunjukkan bahwa biaya pajak tanah petani responden di Kelurahan Taratara Satu untuk musim panen 1 (satu) dan musim panen 2 (dua) rata-rata biaya pajak tanah Rp. 4.929,58 per hektar. Hasil penelitian menunjukkan kesamaan biaya pajak tanah petani responden untuk musim panen 1 (satu) dan musim panen 2 (dua) karena dihitung berdasarkan waktu pembayaran pajak pada setiap tahunnya. Untuk biaya penyusutan peralatan petani responden padi sawah di Kelurahan Taratara Satu untuk musim panen 1 (satu) sebesar Rp. 480.704,79 per hektar dan untuk musim panen 2 (dua) sebesar $\mathrm{Rp}$. 328.451,55 per hektar. Hasil penelitian menunjukkan perbedaan biaya rata-rata penyusutan peralatan responden petani padi sawah di Kelurahan Taratara Satu di pengaruhi oleh kondisi harga dan umur ekonomis alat tersebut.

\section{Biaya Variabel Usahatani Padi Sawah}

Biaya variabel pada usahatani padi sawah di Kelurahan Taratara Satu berdasarkan musim panen 1 (satu) dan musim panen 2 (dua) meliputi biaya pembelian saprodi, penggunaan tenaga kerja, biaya sewa traktor, biaya sewa mesin perontok, dan biaya sewa lahan. Hasil penelitian menunjukkan bahwa perbedaan biaya variabel untuk musim panen 1 (satu) dan musim panen 2 (dua) karena penggunaan biaya yang berbeda-beda. Rata-rata biaya variabel usahatani padi sawah di Kelurahan Taratara Satu berdasarkan musim panen 1 (satu) dan musim panen 2 (dua), tersaji dalam Tabel 21.

Tabel 21. Biaya Variabel Usahatani Padi Sawah berdasarkan Musim Panen

\begin{tabular}{lcc}
\multicolumn{3}{c}{ Sawah berdasarkan Musim Panen } \\
\hline \multirow{2}{*}{ Jenis Biaya } & \multicolumn{2}{c}{ Rata-rata Biaya Variabel } \\
& Panen 1 & Panen 2 \\
\cline { 2 - 3 } & $1.256 .901,41$ & $1.414 .366,20$ \\
\hline $\begin{array}{l}\text { Pembelian } \\
\text { Saprodi }\end{array}$ & & \\
$\begin{array}{l}\text { Penggunaan } \\
\text { Tenaga Kerja }\end{array}$ & $4.092 .957,75$ & $4.863 .380,28$ \\
Sewa Traktor & $1.260 .563,38$ & $1.609 .154,33$ \\
Sewa Mesin & $586.619,72$ & $490.845,07$ \\
$\begin{array}{l}\text { Perontok } \\
\text { Biaya Sewa }\end{array}$ & $1.450 .704,23$ & $1.313 .380,28$ \\
Lahan & & \\
\hline \multicolumn{1}{c}{ Total } & $\mathbf{8 . 6 4 7 . 7 4 6 , 4 8}$ & $\mathbf{9 . 6 9 1 . 1 2 6 , 7 6}$ \\
\hline
\end{tabular}

Sumber : Data Primer, 2016

Tabel 21 menunjukkan bahwa rata-rata biaya variabel usahatani padi sawah di Kelurahan Taratara Satu berdasarkan musim 
panen 1 (satu) dan musim panen 2 (dua), untuk musim panen 1 (satu) sebesar Rp. 8.647.746,48 per hektar dan musim panen 2 (dua) sebesar Rp. 9.691.126,76 per hektar. Komposisi penyusun biaya tersebut digunakan untuk Pembelian saprodi: musim panen 1 (satu) sebesar Rp. 1.256,901,41 per hektar dan musim panen 2 (dua) sebesar Rp. 1.414.366,20 per hektar. Penggunaan tenaga kerja: musim panen 1 (satu) sebesar Rp. 4.092.957,75 per hektar dan musim panen 2 (dua) sebesar Rp. 4.863.380,28 per hektar. Sewa traktor: musim panen 1 (satu) sebesar Rp. 1.260.563,38 per hektar dan musim panen 2 (dua) sebesar Rp. 1.609.154,33 per hektar. Sewa mesin perontok: musim panen 1 (satu) sebesar Rp. 586.619,72 per hektar dan musim panen 2 (dua) sebesar Rp. 490.845,07 per hektar Sewa lahan: musim panen 1 (satu) sebesar Rp. 1.450.704,23 per hektar dan musim panen 2 (dua) sebesar Rp. 1.313.380,28 per hektar.

\section{Biaya Produksi Usahatani Padi Sawah berdasarkan Musim Panen}

Usahatani padi sawah di Kelurahan Taratara Satu tidak terlepas dari beban biaya yang harus di keluarkan dan di perhitungkan oleh petani untuk menghasilkan produksi. Adapun biaya total dari usahatani terdiri dari biaya tetap (fixed cost) dan biaya tidak tetap (variabel cost). Biaya tetap adalah yang relafif jumlahnya dan terus di keluarkan walaupun produksi yang di peroleh banyak atau sedikit, seperti pajak dan penyusutan peralatan. Sedangkan biaya tidak tetap (biaya variabel) adalah biaya yang besar kecilnya di pengaruhi oleh besarnya produksi yang di peroleh yang meliputi pembelian saprodi, penggunaan tenaga kerja, biaya sewa traktor, biaya sewa mesin perontok, dan biaya sewa lahan. Ratarata penggunaan biaya produksi usahatani padi sawah di Kelurahan Taratara Satu berdasarkan musim panen dapat di lihat dalam Tabel 22.

Tabel 22 menunjukkan bahwa rata-rata penggunaan biaya produksi padi sawah di Kelurahan Taratara Satu, berdasarkan musim panen, untuk musim panen 1 (satu) sebesar Rp. 9.133.380,85 per hektar dan musim panen 2 (dua) sebesar Rp. 10.024.507,89 per hektar. Komposisi penyusun biaya tetap untuk musim panen 1 (satu) sebesar Rp 485.634,37 per hektar dan musim panen 2 (dua) sebesar Rp. 333.381,13 per hektar, dan komposisi penyusun biaya variabel untuk musim panen 1 (satu) sebesar Rp. 8.647.746,48 per hektar dan musim panen 2 (dua) sebesar $\mathrm{Rp}$. 9.691.126,76 per hektar.

Tabel 22. Rata-rata Penggunaan Biaya Produksi Usahatani Padi Sawah berdasarkan Musim Panen

\begin{tabular}{lrr}
\hline Penggunaan & \multicolumn{2}{c}{ Rata-rata Biaya (Rp/Ha) } \\
\cline { 2 - 3 } Biaya Produksi & \multicolumn{1}{c}{ Panen 1 } & \multicolumn{1}{c}{ Panen 2 } \\
\hline Biaya Tetap & $485.634,37$ & $333.381,13$ \\
Biaya Variabel & $8.647 .746,48$ & $9.691 .126,76$ \\
\hline \multicolumn{1}{c}{ Total } & $\mathbf{9 . 1 3 3 . 3 8 0 , 8 5}$ & $\mathbf{1 0 . 0 2 4 . 5 0 7 . 8 9}$ \\
\hline
\end{tabular}

Sumber : Data Primer, 2016

\section{Pendapatan Usahatani Padi Sawah berdasarkan Musim Panen}

Nilai pendapatan usahatani yang diterima petani responden di Kelurahan Taratara Satu berdasarkan musim panen, adalah selisih antara total penerimaan dengan total pengeluaran atau biaya, baik biaya tetap maupun biaya variabel. Besarnya pendapatan petani responden berdasarkan musim panen, dihitung dengan menggunakan rumus:

$$
\mathbf{I}=\mathbf{T R}-\mathbf{T C}
$$

Rata-rata pendapatan usahatani padi sawah di Kelurahan Taratara Satu berdasarkan musim panen di sajikan dalam Tabel 23.

\section{Tabel 23. Rata-rata Pendapatan Usahatani Padi Sawah berdasarkan Musim Panen}

\begin{tabular}{lrc}
\hline \multirow{2}{*}{ Uraian } & \multicolumn{2}{c}{ Rata-rata (Rp/Ha) } \\
\cline { 2 - 3 } & \multicolumn{1}{c}{ Panen 1 } & Panen 2 \\
\hline Penerimaan & $31.804 .929,58$ & $28.573 .943,66$ \\
Biaya & $9.133 .380,85$ & $10.024 .507,89$
\end{tabular}

$\begin{array}{lll}\text { Pendapatan } & \mathbf{2 2 . 6 7 1 . 5 4 8 , 7 3} & \mathbf{1 8 . 5 4 9 . 4 3 5 , 7 7}\end{array}$

Sumber : Data Primer, 2016

Tabel 23 menunjukkan bahwa rata-rata pendapatan usahatani padi sawah berdasarkan musim panen di Kelurahan Taratara Satu untuk musim panen 1 (satu) sebesar Rp. 22.671.548,73 per hektar dan musim panen 2 (dua) sebesar Rp. 18.549.435,77 per hektar. 


\section{Nilai R/C Rasio Usahatani Padi Sawah berdasarkan Musim Panen}

Analisis $\mathrm{R} / \mathrm{C}$ rasio adalah perbandingan antara penerimaan dan biaya. Untuk menghitung anilisis $\mathrm{R} / \mathrm{C}$ rasio menggunakan rumus:

$$
\mathbf{a}=\mathbf{R}: \mathbf{C}
$$

Hasil perhitungan analisis $\mathrm{R} / \mathrm{C}$ rasio usahatani padi sawah di Kelurahan Taratara Satu berdasarkan musim panen untuk musim panen 1 (satu) dan musim panen 2 (dua) adalah sebagai berikut:

\section{Musim Panen $1 \quad \mathrm{a}=\mathrm{R}: \mathrm{C}$ \\ $\mathrm{a}=31.804 .929,58 / 9.133 .380,85$ \\ $\mathrm{a}=3,48$}

Nilai $\mathrm{R} / \mathrm{C}$ rasio untuk musim panen 1 (satu) sebesar 3,48 yang artinya bahwa setiap pengeluaran Rp. 1 akan menghasilkan penerimaan sebesar Rp. 3,48.

\section{Musim Panen 2 $\mathrm{a}=\mathrm{R}: \mathrm{C}$ $\mathrm{a}=28.573 .943,66: 10.024 .507,89$ \\ $\mathrm{a}=2,85$}

Nilai R/C rasio untuk musim panen 2 (dua) sebesar 2,85 yang artinya bahwa setiap pengeluaran Rp. 1 akan menghasilkan penerimaan sebesar Rp. 2,85.

Nilai R/C rasio lebih dari satu menunjukkan bahwa usahatani tersebut untuk musim panen 1 (satu) sebesar 3,48 dan musim panen 2 (dua) sebesar 2,85 mampu memberikan keuntungan sebesar 3,48 kali untuk musim panen 1 (satu) dan 2,85 kali untuk musim panen 2 (dua) dari biaya yang di keluarkan. Dengan demikian dapat disimpulkan bahwa usahatani padi sawah di Kelurahan Taratara Satu yang dikelolah oleh petani responden untuk musim panen 1 (satu) dan musim panen 2 (dua) relativ memberikan keuntungan sehingga usahatani padi sawah di Kelurahan Taratara Satu untuk musim panen 1 (satu) dan musim penen 2 (dua) layak untuk di kelolah oleh petani karena memberikan keuntungan, dan usahatani padi sawah tersebut mampu meningkatkan taraf hidup petani responden padi sawah.

\section{Ringkasan Perbedaan Musim Panen 1 (satu) dan Musim Panen 2 (dua)}

Usahatani padi sawah di Kelurahan Taratara Satu untuk musim panen 1 (satu) dan musim panen 2 (dua) berbeda. Untuk jumlah produksi musim panen 1 (satu) sebesar $3.347,89 \mathrm{~kg}$ per hektar dan musim panen 2 (dua) sebesar 2.857,39 kg per hektar. Perbedaan untuk jumlah produksi dikarenakan kondisi iklim yang berubah-rubah sehingga menyebabkan jumlah produksi berubah.

Harga jual untuk musim panen 1 (satu) sebesar Rp. 9.500/kg dan musim panen 2 (dua) sebesar Rp. 10.000/kg Perbedaan untuk harga jual musim panen 1 (satu) dan musim panen 2 (dua) dikarenakan harga jual beras pada setiap tahunya meningkat.

Biaya sarana produksi untuk musim panen 1 (satu) sebesar Rp. 1.256.901,41 per hektar dan musim panen 2 (dua) sebesar Rp. 1,414.366,20 per hektar. perbedaan untuk biaya sarana produksi dikarenakan harga saprodi yang mengalami kenaikan.

Biaya penyusutan peralatan untuk musim panen 1 (satu) sebesar Rp. 480.704,79 per hektar dan musim panen 2 (dua) sebesar Rp. 328.451,55 per hektar. Perbedaan untuk biaya penyusutan peralatan untuk musim panen 1 (satu) dan musim panen 2 (dua) dikanenakan kondisi harga dan umur ekonomis alat tersebut.

Biaya tenaga kerja umtuk musim panen 1 (satu) sebesar Rp. 4.092.957,75 per hektar dan musim panen 2 (dua) sebesar Rp. 4.865.281,69 per hektar. Perbedaan untuk biaya tenaga kerja pada musim panen 1 (satu) dan musim panen 2 (dua) dikarenakan harga upah tenaga kerja pada setiap tahunya mengalami kenaikan. Biaya sewa lahan untuk musim panen 1 (satu) sebesar Rp. 1.450.704,23 per hektar dan musim panen 2 (dua) sebesar Rp. 1.313.380,28 per hektar dan biaya sewa mesim perontok untuk musim panen 1 (satu) sebesar Rp. 586.619,72 per hektar dan musim panen 2 (dua) sebesar Rp. 490.845,07 per hektar. Perbedaan biaya sewa lahan dan biaya sewa traktor dikarenakan jumlah produksi yang berbeda.

Biaya sewa traktor untuk musim panen 1 (satu) sebesar Rp. 1.260.563,38 dan musim panen 2 (dua) sebesar Rp. 1.609.154,93 per hektar. Perbedaan untuk biaya sewa traktor pada musim panen 1 (satu) dan musim panen 2 (dua) dikarenakan kondisi tanah yang sulit dibajak, karena pada musim panen 1 (satu) perairan disawah baik, sehingga proses 
pembajakan tidak terlalu sulit dan struktuk tanah tidak keras, sedangkan pada musim panen 2 (dua) stuktur tanah keras karena kemarau panjang, sehingga debit air berkurang sehingga air yang mengairi tanah persawahan berkurang sehingga menyebapkan struktur tanah menjadi keras.

Biaya tetap untuk musim panen 1 (satu) sebesar Rp. 485.634,37 per hektar dan musim panen 2 (dua) sebesar Rp. 333.381,13 per hektar. Perbedaan biaya tetap untuk musim panen 1 (satu) dan musim panen 2 (dua) dikarenakan biaya penyusutan peralatan. Biaya variabel untuk musim panen 1 (satu) sebesar Rp. 8.647.746,48 per hektar dan musim panen 2 (dua) sebesar $\mathrm{Rp}$. 9.691.126,76 per hektar. Perbedaan biaya variabel untuk musim panen 1 (satu) dan musim panen 2 (dua) dikarenakan penggunaan biaya yang berbeda-beda.

Penerimaan untuk musim panen 1 (satu) sebesar Rp. 31.804.929,58 per hektar dan musim panen 2 (dua) sebesar Rp. 28.573.943,66 per hektar. Perbedaan penerimaan untuk musim panen 1 (satu) dan musim panen 2 (dua) di karenakan jumlah produksi dan harga jual yang berbeda. Total biaya untuk musim panen 1 (satu) sebesar Rp. 9.133.380,85 per hektar dan musim panen 2 (dua) sebesar Rp. 10.024.507,89 per hektar.
Perbedaan total biaya untuk musim panen 1 (satu) dan musim panen 2 (dua) dikarenakan biaya variabel, biaya sewa traktor, biaya tenaga kerja, dan biaya sarana produksi yang tinggi yang menunjukkan kosentrasi perbandingan pada musim panen 2 (dua) dan juga karena kondisi umur ekonomis barang dan harga biaya yang berbeda-beda pada setiap tahunya.

Pendapatan untuk musim panen 1 (satu) sebesar Rp. 22.671.548,73 per hektar dan musim panen 2 (dua) sebesar $\mathrm{Rp}$. 18.549.435,77 per hektar. Perbedaan pendapatan untuk musim panen 1 (satu) dan musim panen 2 (dua) dikarenakan jumlah produksi pada musim panen 1(satu) lebih banyak dari pada jumlah produksi pada musim panen 2 (dua) dan total biaya untuk musim panen 1 (satu) lebih sedikit dari pada musim panen 2 (dua).

Nilai $\mathrm{R} / \mathrm{C}$ rasio untuk musim panen 1 (satu) sebesar 3,48 dan musim panen 2 (dua) sebesar 2,85. Perbedaan untuk nilai $\mathrm{R} / \mathrm{C}$ rasio untuk musim panen 1 (satu) dan musim panen 2 (dua) dikarenakan penerimaan untuk musim panen 1 (satu) lebih besar dari pada musim panen 2 (dua) dan total biaya untuk musim panen 1 (satu) lebih sedikit dari pada musim panen 2 (dua). Perbedaan untuk musim panen 1 (satu) dan musim panen 2 (dua) tersaji dalam Tabel 24.

Tabel 24. Perbedaan Musim Panen 1 (satu) dan musim panen 2 (dua) Dalam Jumlah Produksi, Harga Jual, Penerimaan, Biaya, Pendapatan dan Nilai R/C

\begin{tabular}{|c|c|c|c|}
\hline \multirow[b]{2}{*}{ Uraian } & \multicolumn{2}{|c|}{ Perbedaan (Kg/Rp/Ha) } & \multirow[t]{2}{*}{ Keterangan } \\
\hline & Panen 1 & Panen 2 & \\
\hline Jumlah Produksi & $3.347,89$ & $2.857,39$ & Panen $1>$ Panen 2 \\
\hline Harga Jual & 9.500 & 10.000 & Panen $1<$ Panen 2 \\
\hline Sarana Produksi & $1.256 .901,41$ & $1.414 .366,20$ & Panen $1<$ Panen 2 \\
\hline Biaya Penyusutan Peralatan & $480.704,79$ & $328.451,55$ & Panen $1>$ panen 2 \\
\hline Biaya Tenaga Kerja & $4.092 .957,75$ & $4.865 .281,69$ & Panen $1<$ Panen 2 \\
\hline Biaya Sewa Lahan & $1.450 .704,23$ & $1.313 .380,28$ & Panen $1>$ Panen 2 \\
\hline Biaya Sewa Traktor & $1.260 .563,38$ & $1.609 .154,93$ & Panen $1<$ Panen 2 \\
\hline Biaya Sewa Mesin Perontok & $586.619,72$ & $490.845,07$ & Panen $1>$ Panen 2 \\
\hline Biaya Tetap & $485.634,37$ & $333.381,13$ & Panen $1>$ Panen 2 \\
\hline Biaya Variabel & $8.647 .746,48$ & $9.691 .126,76$ & Panen $1<$ Panen 2 \\
\hline Penerimaan & $31.804 .929,58$ & $28.573 .943,66$ & Panen $1>$ Panen 2 \\
\hline Total Biaya & $9.133 .380,85$ & $10.024 .507,89$ & Panen $1<$ Panen 2 \\
\hline Pendapatan & $22.671 .548,73$ & $18.549 .435,77$ & Panen $1>$ Panen 2 \\
\hline Nilai R/C Ratio & 3,48 & 2,85 & Panen $1>$ Panen 2 \\
\hline
\end{tabular}

Sumber : Data Primer, 2016 
Tabel 24 menunjukkan bahwa perbedaan untuk jumlah produksi, harga jual, biaya-biaya, penerimaan, pendapatan dan nilai $\mathrm{R} / \mathrm{C}$ ratio untuk musim panen 1 (satu) dan musim panen 2 (dua) terlihat konsentrasi perbandingan berada pada musim panen 1 (satu). Penyusun kosentrasi perbandingan pada musim panen 1 (satu) terdiri atas: jumlah produksi sebesar $3.347,89 \mathrm{~kg} / \mathrm{ha}$, biaya penyusutan peralatan sebesar Rp. 480.704,79 per hektar, biaya sewa lahan sebesar Rp. 1.450.704,23 per hektar, biaya sewa mesin perontok sebesar Rp. $586.619,72$ per hektar, biaya tetap sebesar Rp. 485.634,37 per hektar, penerimaan sebesar Rp. 31.804.929,58 per hektar, pendapatan Rp. 22.671.548,73 per hektar dan nilai $\mathrm{R} / \mathrm{C}$ ratio sebesar 3,48. Penyusun konsentrasi perbandingan untuk musim panen 2 (dua) terdiri atas: harga jual Rp. $10.000 / \mathrm{kg}$ beras, biaya sarana produksi sebesar Rp. 1.414.366,20 per hektar, biaya tenaga kerja sebesar Rp. 4.865.281,69 per hektar, biaya sewa traktor sebesar Rp. 1.609.154,93 per hektar, biaya variabel sebesar Rp. 9.691.126,76 per hektar, dan total biaya sebesar Rp. 10.024.507,89 per hektar.

\section{KESIMPULAN DAN SARAN}

\section{Kesimpulan}

1. Berdasarkan hasil Penelitian pendapatan usahatani padi sawah yang di kelolah oleh petani responden di Kelurahan Taratara Satu berdasarkan musim panen, untuk musim panen 1 (satu) dan musim panen 2 (dua) berbeda. Hal tersebut dipengaruhi oleh iklim, harga jual dan biaya.

2. Nilai $\mathrm{R} / \mathrm{C}$ rasio lebih dari satu, artinya usahatani padi sawah di Kelurahan Taratara Satu mampu memberikan keuntungan dan usahatani tersebut layak untuk di usahakan.

\section{Saran}

1. Usahatani padi sawah di Kelurahan Taratara Satu, layak untuk diusahakan, oleh karena itu pemerintah dan petani harus bekerja sama dalam meningkatkan produksi usahatani padi sawah, agar usahatani padi sawah tidak hanya diusahakan namun juga lebih dikembangkan.
2. Petani harus mempertahankan penggunaan benih/bibit yang bersertifikat agar supaya produksi usahatani lebih meningkat.

3. Diperlukan penelitian lebih lanjut terutama mengenai efisiensi penggunaan faktorfaktor produksi padi sawah, agar diketahui apakah pendapatan yang diperoleh tersebut berdasarkan penggunaan faktor-faktor produksi yang tepat atau tidak.

\section{DAFTAR PUSTAKA}

Badan Pusat Statistik Kota Tomohon. 2016. Tomohon Dalam Angka 2015.

Bambang., Arisanti. 2007. Mengasah Kemampuan Ekonomi. Citra Praya. Bandung.

Damayanti, F. 2007. Analisis Pendapatan dan Efisiensi Produksi Usahatani Padi sawah (Studi Kasus Di Desa Purwodadi Kecamatan Trimurjo Kabupaten Lempung tengah). Skripsi. Fakultas pertanian. Institut Pertanian Bogor.

Daniel, M. (2002). Pengantar Ekonomi Pertanian. Jakarta. PT. Bumi Aksara.

Fuad, M., Christian, H., Nurlela., Sugiarto., Paulus, Y. E. F. 2003. Pengantar Bisnis. Edisi Ketiga. Gramedia Pustaka Utama. Jakarta.

Ilham,T. 2010. Diversifikasi Pangan dan Penyuluhan Pertanian Sebagai Upaya Mewujudkan Ketahanan Nasional. Kompas. Diakses pada tanggal 2 Februari 2016.

Iqbal, M. 2014. Peranan Kelompok Tani Dalam Meningkatkan Pendapatan Petani Padi Sawah Di Desa Margamulya Kecamatan Bungku Barat Kabupaten Morowali. Agrotekbis, 2(5).

Kantor Kelurahan Taratara Satu. 2016. Profil Kelurahan Taratara Satu Tahun 2015.

Kaparang, G. 2015. Kajian Usahatani Padi Sawah Di Kelurahan Taratara Satu Kota Tomohon. Skripsi, Fakultas Pertanian, Universitas Sam Ratulangi Manado.

Lynn. 2013. Pembangunan Pertanian. http://id. Scribd. com/doc/198042799/pengertianpembangunan-pertanian Diakses pada tanggal 2 Februari 2016.

Mubyarto. 1994. Pengantar Ekonomi Pertanian. LP3ES. Jakarta. 
Noor, N. 2007. Peranan Akuntansi Pertanggungjawaban Dalam Menunjang Efektivitas Pengendalian Biaya Produksi Studi Kasus Pada PT. Indonesia Asahan Alumunium (Doctoral dissertation, Universitas Widyatama).

Pindyck, R. S., D. L. Rubinfeld. 2001. Microeconomics. Fifth Edition. New York: Prentice Hall Internasional, Inc.

Rahim, Abd., Hastuti., Drw. 2007. Ekonomi pertanian. Penebar Swadaya. Jakarta.

Soekartawi. 2002. Analisis Usahatani. Penerbit Universitas Indonesia (Ui-Press). Jakarta. 2002. Ilmu Usahatani Dan Penelitian Untuk Pengembangan Petani Kecil. Universitas Indonesia Press. Jakarta.

Sukirno, Sadono. 2006. Pengantar Teori Mikro Ekonomi. Penerbit: PT Raja Grafindo. Jakarta.
Supartama Made. 2013. Analisis Pendapatan Dan Kelayakan Usahatani Padi sawah Di Subak Baturiti Desa Balinggi Kecamatan Balinggi Kabupaten Parigi Moutong. https://M1. Scribd. com/Doc/205551759/Analisis-

Pendapatan-dan-Kelayakan-Usahatani-

Padi. Diakses pada tanggal 11 Februari 2016.

Suwarto. 2012. Produktivitas Lahan Usahatani Sesuai Kelembagaan Lahan. https: //eprints. uns. ac. id/12634/1/publikasi jurnal_(44). pdf. Diakses pada tanggal 11 Juni 2016.

Yanti. 2012. Analisis Pendapatan Petani Kelapa Di Kecamatan Saliabu Kabupaten Talaud. Skripsi, Fakultas Pertanian, Universitas Sam Ratulangi Manado. 